\title{
Методологія оцінки допустимих товщин елементів трубопроводів AEC із вуглецевих сталей в умовах ерозійно-корозійного зносу
}

\author{
- Агеєв Сергій Михайлович, канд. техн. наук \\ ТОВ «ІПП-Центр», м. Київ, Україна \\ ORCID: https://orcid.org/0000-0003-0292-8024
}

\begin{abstract}
У статті описано підхід до оцінки ступеня небезпеки ерозійно-корозійного зносу елементів трубопроводів AEC із вуглецевих сталей. 3 метою апробації запропонованого підходу проведено комплекс розрахунково-аналітичних робіт, зокрема: а) проаналізовано існуючий підхід до оцінки ступеня небезпеки ерозійно-корозійного зносу на АЕС України; встановлено його недоліки; б) розроблено алгоритм оцінки ступеня небезпеки ерозійно-корозійного зносу з використанням експрес-оцінки та уточненої процедури; в) верифіковано розрахункові моделі співставленням з іншими існуючими розрахунковими моделями та експериментальними даними $з$ метою демонстрації їх коректності; г) за розробленим підходом виконано оцінку ступеня небезпеки ерозійно-корозійного зносу систем трубопроводів енергоблоків №№ 1 та 4 Відокремленого підрозділу «Запорізька атомна електростанція», виявлених у період експлуатації з 2012 року по 2016 рік.

Розроблений підхід дозволяє: 1) оцінювати ступінь небезпеки ерозійно-корозійного зносу не тільки в окружному напрямку поперечного перерізу труби внаслідок дії внутрішнього тиску (підхід, що базується на вимогах ПНАЭ Г-7-002-86, щодо визначення допустимої товщини стінки бездефектного трубопроводу), але й уздовж осі трубопроводу від одночасної дії внутрішнього тиску, осьового зусилля та моментів згину. Такий підхід особливо актуальний для трубопровідних систем, які, переважно, мають складну просторову конфігурацію, що призводить до виникнення в них осьових зусиль та моментів згину внаслідок дії масових характеристик трубопроводів та арматури, температурних, сейсмічних впливів тощо; 2) оцінювати ступінь небезпеки ерозійно-корозійного зносу не тільки за його глибиною (підхід ИН-Т.0.03.190-14), а й 3 урахуванням довжини та ширини ерозійно-корозійного зносу. На відміну від існуючого підходу, це дозволяє коректніше оцінювати ступінь небезпеки ерозійно-корозійного зносу.
\end{abstract}

Ключові слова: АЕС, трубопровід, ерозійно-корозійний знос, міцність, експрес-оцінка, уточнена аналітична процедура.

(c) Агеєв C. М., 2021

\section{Загальні відомості}

Висока надійність та високі експлуатаційні показники енергоблоків BВEP-1000 та BВEP-440, зокрема обладнання та трубопроводів першого контуру, забезпечуються за умов приділення достатньої уваги другому контуру. Наприклад, на енергоблоках АEC Ловійса (Фінляндія) та Пакш (Угорщина) з метою зниження ерозійно-корозійного зносу (ЕКЗ) модернізовано обладнання другого контуру. Коефіцієнт використання встановленої потужності після модернізації мав вищі значення порівняно з енергоблоками AEC з PWR [1].
Елементи обладнання та трубопроводів другого контуру з вуглецевих сталей, переважно, експлуатуються як в умовах однофазного (водного), так і двофазного (вода, пара) середовищ, що супроводжується виносом у нього залізовмісних продуктів загальної ерозії-корозії та локальними (в каналах складної геометрії) ерозійно-корозійними пошкодженнями. Тому, процес ЕКЗ характеризується стоншенням стінок в одних місцях обладнання i трубопроводів (винос матеріалу) та потовщенням стінок в інших зонах (відкладення). Стоншення призводить до порушення міцності, потовщення - до ускладнення течії середовища. 
Незалежно від типу реакторної установки, проблема ЕКЗ притаманна практично всім АЕС. Причому 39 \% усіх пошкоджень обладнання та трубопроводів AЕC припадає на механізм ерозії-корозії [2]. Згідно з експлуатаційними даними АЕС Франції ЕКЗ охоплює 58 \% подій, що впливають на безпеку AEC [3].Такіпошкодження, якправило, на заключній стадії призводять до виникнення свищів. Заразом, відомо не мало випадків, коли через недостатній контроль ЕКЗ на обладнанні відбувались аварійні ситуації: ерозія-корозія трубопроводу живильної води на АEC «Саррі» (США) [4]; ерозійно-корозійний розмив двох трубопроводів діаметром 152 мм на енергоблоці № 3 AEC «Мілстоун» (США), що супроводжувався викидом пари та води в турбінне відділення [5]; розрив трубопроводу між підігрівачем низького тиску та деаератором внаслідок ЕКЗ на AEC «Міхама» (Японія) [6]; руйнування трубопроводу живильної води на ділянці після вимірювальної діафрагми внаслідок ЕКЗ на АЕC «Какрапар» (Індія) [7]. На трубопроводах другого контуру АЕC Південної Кореї, починаючи з середини 90-х років минулого століття, траплялися стоншення стінок, свищі та руйнування, пов'язані з ЕК3 [8]. Це далеко не повний перелік усіх аварійних інцидентів, пов'язаних з ЕКЗ обладнання та трубопроводів другого контуру, що виникали на АEC.

Статистика виявлення ЕК3 на трубопроводах АЕС України свідчить, що переважно цей тип пошкоджень характерний трубопроводам другого контуру. Так, проведені на енергоблоці № 1 Відокремленого підрозділу «Южно-Українська атомна електростанція» дослідження показали [9], що найбільш схильними до ЕК3 (за зменшенням ступеня схильності) $є$ дренажні трубопроводи, трубопроводи живильної води, трубопроводи основного конденсату, трубопроводи гострої та гріючої пари тощо. Основна кількість замірів припадає на інтервал стоншень 1-3 мм (82,4 \%, 83,2 \%, 89,2 \%, 100 \% трубопроводи живильної води, конденсату гріючої пари, основного конденсату, гострої та гріючої пари відповідно). Водночас, мали місце суттєвіші стоншення: на інтервал стоншень 4-6 мм для вказаних систем трубопроводів відповідно припадає 10,8 \%, $16,1 \%, 4,8 \%$ та 8,3 \% замірів; на стоншення 7-9 мм відповідно 6,5 \%, 0,7 \%, 6,0 \% та 2,8 \% замірів.

Явище ЕКЗ є складним і залежить від низки факторів, а саме:

гідродинаміки потоку робочого середовища, зокрема розмірів та геометричних особливостей проточної частини елементу та ділянки загалом, розходу (швидкості) робочого середовища, ступеня вологості пари, концентрації кисню середовища тощо;

хімічного складу металу, насамперед вміст хрому, молібдену, міді.

внутрішнього тиску та температури теплоносія; параметрів водно-хімічного режиму; історії експлуатації: результатів контролю товщини, даних щодо проведених ремонтів та замін, напрацювань тощо.

Важливою характеристикою ерозійно-корозійного процесу $\epsilon$ швидкість. Отримавши швидкість ЕК3 та знаючи допустиме стоншення стінки, можна не тільки оптимізувати експлуатаційний контроль, але й запобігти можливим аварійний ситуаціям.

Аварія на AEC «Саррі» (США) [4] зумовила поштовх до розробок комп'ютерних кодів для розрахунку швидкості ЕКЗ. Прогноз ЕКЗ, як правило, виконується двома способами: емпіричним та напівемпіричним [10]. Так, використовуючи емпіричний підхід, спеціалістами інституту EPRI (США) розроблено комп'ютерний код CHECWORKS, в основі якого лежать отримані за результатами лабораторного і експлуатаційного контролю емпіричні кореляційні залежності геометрії, хімічного складу, водно-хімічного режиму, температури, швидкості потоку, напрацювання тощо. Емпіричний підхід використано під час розробки таких комп'ютерних кодів, як WATHEC і DASY, зокрема для AEC Німеччини. Комп'ютерний код COMSY розроблено спільними зусиллями спеціалістів Німеччини та Франції. У Росії з використанням емпіричного підходу створено програмні коди ЭКИ-02 для розрахунку швидкості ЕК3 в умовах однофазного середовища для АЕС 3 BВЕР-440, та ЭКИ-03 - в умовах двофазного середовища [11]. Напівемпіричний підхід покладено в основу кодів BRT-CICERO (EDF) та РАМЭК-1 (Росія).

Контроль ЕКЗ на енергоблоках АЕС України, так само як і на AEC інших країн, запровадили після 1986 року. Контроль товщин стінок трубопроводів у процесі введення в експлуатацію АЕC не проводили. Ба більше, нормативної та експлуатаційної документації з питань ЕК3 не існувало.

На сьогодні в Україні діє документ COУ HAEK 040:2017 [12], що встановлює загальні вимоги до управління старінням трубопроводів AЕС, схильних до ЕК3. СОУ НАЕК 040:2017 [12] передбачає використання системного підходу до управління старінням, що являє собою адаптацію циклу Демінга. Передбачено виконання оцінки швидкості ЕК3, встановлення критеріїв допустимості та оцінку ступеня їх небезпеки.

Мета статті - розробка науково обґрунтованого підходу до оцінки допустимих товщин стінок елементів трубопроводів, схильних до ЕКЗ. Ступінь небезпеки ЕКЗ (або допустиму товщину стінки трубопроводу) пропонується оцінювати відповідно до запропонованих критеріїв із встановленням подальших заходів: дозвіл на подальшу експлуатацію; виконання додаткової уточненої оцінки ЕК3; ремонт.

Методи оцінки швидкості ЕКЗ у цій статті не розглядаються. Водночас, очевидним $\epsilon$ той факт, що без розрахунку швидкості ЕКЗ ефективне планування об'ємів контролю та ремонтних робіт неможливе. 
Аналіз існуючого підходу до оцінки ступеня небезпеки ЕКЗ трубопроводів АЕС України

На сьогодні оцінка ступеня небезпеки ЕКЗ персоналом АЕС України виконується винятково за допомогою спрощеної процедури, що базується на вимогах норм на проєктування [13]. Експлуатаційна документація (інструкції, методичні рекомендації тощо) $з$ оцінки товщин стінок трубопроводів AEC України розроблена з урахуванням вимог уніфікованої інструкції [14], відповідно до яких як критеріальні (мінімально допустимі) товщини стінки використовуються значення, отримані за результатами розрахунку з вибору основних розмірів бездефектних елементів трубопроводів згідно з нормами на проєктування [13]. Такий підхід [14], на відміну від повірочного розрахунку, регламентує оцінку ЕКЗ від дії тільки одного фактора навантаження - внутрішнього тиску.

Системи трубопроводів 2-го контуру, власне як і інші трубопроводи АЕС, характеризуються складною просторовою конфігурацією. Очевидно, це спричиняє виникнення в них зусиль та моментів. Вказані силові фактори виникають унаслідок дії таких навантажень, як маса трубопроводу та встановленої арматури, температурні і сейсмічні впливи тощо.

Прийнято вважати, що стоншення ерозійно-корозійної природи в загальному випадку не $\epsilon$ односпрямованими. Через це оцінювати ступінь небезпеки ЕКЗ коректно у двох характерних напрямках - осьовому (вздовж осі трубопроводу) і окружному (в поперечному перерізі труби).

Оцінювання ЕКЗ лише в одному напрямку (в окружному напрямку від дії внутрішнього тиску), як це регламентується інструкцією [14], очевидно, призведе до переоцінки залишкової міцності трубопроводу з ЕКЗ. Це означає, що визначена в такий спосіб міцність трубопроводу $\epsilon$ більшою за його фактичну міцність, а, значить, дає неконсервативні результати.
Запропонований у статті підхід уникає зазначених вище недоліків, адже згідно з його положеннями небезпека ЕКЗ оцінюється з урахуванням ослаблення міцності трубопроводу як в окружному напрямку внаслідок дії внутрішнього тиску, так і в осьовому напрямку з урахуванням одночасної дії тиску, зусиль та моментів.

Крім того, розроблений підхід враховує не тільки глибину ЕК3, як це передбачено інструкцією [14], а також його ширину і довжину.

Отже, на відміну від існуючого підходу, основаного на визначенні допустимої товщини стінки трубопроводу без дефекту, розроблена процедура безпосередньо призначена для оцінки дефектів типу ЕК3 з урахуванням усього можливого спектра навантажень.

Порівняння існуючого підходу до оцінки ступеня небезпеки ЕК3, що базується на вимогах уніфікованої інструкції [14], із запропонованим у цій статті підходом для зручності наведено в Таблиці 1.

\section{Основні аспекти розробленого підходу до оцінки ЕК3}

Метою розробленого підходу $\epsilon$ допуск трубопроводу з ЕКЗ в експлуатацію до наступного експлуатаційного контролю за допомогою розрахунково-аналітичного обґрунтування. Передбачається виконання оцінки цілісності елементу трубопроводу з ЕКЗ або визначення допустимої товщини стінки трубопроводу 3 урахуванням геометрії трубопроводу та ЕК3, навантаження (внутрішній тиск, зусилля, моменти згину), фізико-механічних характеристик матеріалу труби.

Ступінь небезпеки ЕКЗ оцінюється для таких елементів: прямолінійний елемент, коліно, трійник, конусний перехідник.

Таблиця 1 - Переваги та недоліки запропонованого підходу, порівняно з існуючим підходом на основі вимог [14]

\begin{tabular}{|l|c|c|}
\hline \multicolumn{1}{|c|}{ Параметр оцінки ЕК3 } & $\begin{array}{c}\text { Існуючий підхід } \\
\text { на основі [14] }\end{array}$ & Запропонований підхід \\
\hline $\begin{array}{l}\text { Геометричні характеристики трубопроводу: } \\
\text { радіус, товщина стінки }\end{array}$ & Враховує повністю & Враховує повністю \\
\hline $\begin{array}{l}\text { Геометричні характеристики стоншення в } \\
\text { осьовому напрямку труби: глибина, довжина }\end{array}$ & $\begin{array}{c}\text { Враховує тільки глибину } \\
\text { стоншення }\end{array}$ & $\begin{array}{c}\text { Враховує повністю } \\
\text { (експрес-оцінка) }\end{array}$ \\
\hline $\begin{array}{l}\text { Геометричні характеристики стоншення в } \\
\text { окружному напрямку труби: глибина, ширина }\end{array}$ & $\begin{array}{c}\text { Враховує тільки глибину } \\
\text { стоншення }\end{array}$ & $\begin{array}{c}\text { Враховує повністю } \\
\text { (експес-оцінка, уточнена } \\
\text { процедура) }\end{array}$ \\
\hline $\begin{array}{l}\text { Напружено-деформований стан (НДС) } \\
\text { стоншеного трубопроводу: внутрішній тиск, } \\
\text { момент згину, осьове зусилля }\end{array}$ & $\begin{array}{l}\text { Враховує тільки } \\
\text { внутрішній тиск }\end{array}$ & $\begin{array}{c}\text { Враховує повністю } \\
\text { (уточнена процедура) }\end{array}$ \\
\hline
\end{tabular}


Запропонований у статті підхід базується на двох положеннях: по-перше, наявність ЕКЗ збільшує розрахункові референсні напруження, по-друге, збільшуються на 10 \% напруження, що відповідають допустимому згідно з нормами на проєктування [13] стану. Останнє положення узгоджується з сучасними нормативними документами як України, так і інших держав, зокрема, зі стандартом Американського нафтового інституту [15], російською [16] та українською [17] методиками. Відомо, що рівень допустимих напружень для бездефектної конструкції згідно 3 нормами на проєктування [13] встановлюється 3 урахуванням невизначеностей, зокрема, пов'язаних із наявністю дефектів. Оскільки розроблений підхід розглядає встановлене із заданою точністю ЕКЗ, збільшення на 10 \% допустимих напружень, з огляду на наведене вище, $\epsilon$ обгрунтованим.

Розроблений підхід застосовується для ЕК3, довжина і ширина яких значно більші за глибину,
3 можливістю їх аналізу в осьовому та окружному напрямках. Підхід не розглядає тріщину. Водночас, для аналізу вузьких несуцільностей необхідно використовувати двокритеріальний підхід механіки руйнування, відповідно до якого оцінці підлягає як в'язка, так і крихка складові руйнування [12]. Заразом, запропонований підхід не регламентує тривалість міжконтрольного періоду або тривалість експлуатації трубопроводу залежно від швидкості ЕКЗ.

Розроблений підхід встановлює порядок оцінки ступеня небезпеки ЕКЗ через співставлення зафіксованих розмірів ЕКЗ 3 відповідними критеріальними значеннями - експрес-оцінка, та, за необхідності, додаткового (уточненого) розрахунку допустимої товщини стінки. Блоксхему оцінки ступеня небезпеки ЕКЗ зображено на Рисунку 1. Логіка ухвалення рішень детально описана нижче.

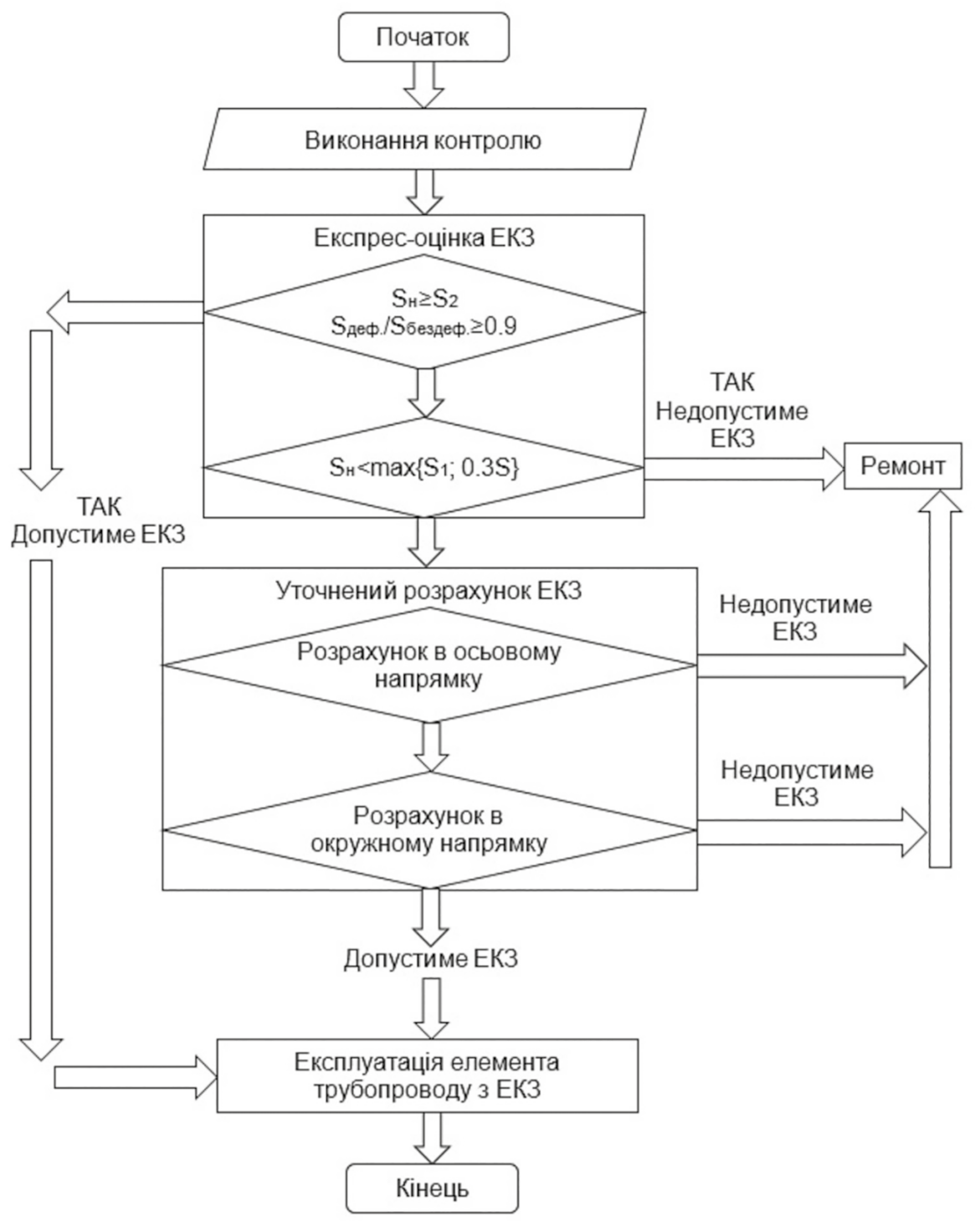

Рисунок 1 - Блок-схема оцінки ступеню небезпеки ЕК3 


\section{Експрес-оцінка ЕКЗ}

Експрес-оцінка передбачає аналіз ступеня небезпеки ЕКЗ без виконання трудомістких розрахунків. Виконується порівняння встановленої за результатами контролю мінімальної товщини стінки в зоні ЕК3 із відповідними допустимими значеннями, отриманими для широкого діапазону типорозмірів трубних елементів, матеріалів та експлуатаційних факторів.

За результатами експрес-оцінки ухвалюється одне з рішень: допуск в експлуатацію; виконання додаткового (уточненого) розрахунку; ремонт.

Ступінь небезпеки ЕКЗ оцінюється у такий спосіб:

1. Якщо $\left(\mathrm{S}_{\text {деф. }} / \mathrm{S}_{\text {бездеф. }}\right) \geq 0,9$, та одночасно $\mathrm{S}_{\min } \geq \mathrm{S}_{2^{\prime}}$ то ЕКЗ вважається допустимим, трубопровід допускається в експлуатацію.

2. Якщо $\left(\mathrm{S}_{\text {деф. }} / \mathrm{S}_{\text {бездеф. }}\right) \geq 0,9$, та одночасно $\max \left\{\mathrm{s}_{1} ; 0,3 \mathrm{~s}\right\} \leq \mathrm{s}_{\min }<\mathrm{s}_{2}$, то ЕК3 підлягає додатковому (уточненому) розрахунку.

3. Якщо $\left(\mathrm{S}_{\text {деф. }} / \mathrm{S}_{\text {бездеф. }}\right)<0,9$, та одночасно $\mathrm{s}_{\min } \geq \mathrm{s}_{2}$, то ЕК3 підлягає додатковому (уточненому) розрахунку.

4. Якщо $\left(\mathrm{S}_{\text {деф. }} / \mathrm{S}_{\text {бездеф. }}\right)<0,9$, та одночасно $\max \left\{\mathrm{s}_{1} ; 0,3 \mathrm{~s}\right\} \leq \mathrm{s}_{\min }<\mathrm{s}_{2}$, то ЕК3 підлягає додатковому (уточненому) розрахунку.

5. Якщо $\mathrm{s}_{\min }<\max \left\{\mathrm{s}_{1} ; 0,3 \mathrm{~s}\right\}$, то ЕK3 підлягає ремонту за будь-якого значення $\left(\mathrm{S}_{\text {деф. }} / \mathrm{S}_{\text {бездеф. }}\right)$.

Наведені вище алгоритм дій та відповідна йому блок-схема (див. Рисунок 1) використовують такі позначення:

$\mathrm{S}_{\text {бездеф. }}$ - площа бездефектного поперечного перерізу (див. Рисунок 2a);

$\mathrm{S}_{\mathrm{EK} 3}$ - площа схематизованого ЕК3 постійної глибини;

$\psi$ - половина кута, на який спирається ЕКЗ в окружному напрямку поперечного перерізу трубопроводу (див. Рисунок 26);

$\mathrm{S}_{\text {деф. }}$ - площа поперечного перерізу в зоні ЕК3, що відповідає максимальному стоншенню (див. Рисунок 26);

$\mathrm{s}_{\text {min }}$ - найменше значення товщини стінки елементу трубопроводу в зоні ЕК3, що відповідає найбільшій глибині ЕK3;

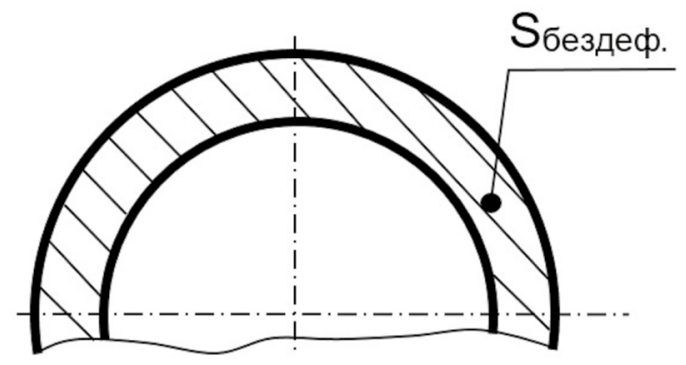

a) s - номінальна товщина стінки бездефектного елементу трубопроводу;

$\mathrm{s}_{1}$ - нижня границя мінімально допустимої товщини стінки елементу трубопроводу;

$\mathrm{S}_{\mathrm{R}}$ - розрахункова товщина стінки елементу трубопроводу;

$\mathrm{s}_{2}$ - верхня границя мінімально допустимої товщини стінки елементу трубопроводу.

a - безрозмірний коефіцієнт зменшення міцності або безрозмірний внутрішній тиск, що відповідає граничному стану трубопроводу з ЕКЗ в окружному напрямку, $0 \leq a \leq 1$ ( $a=0$ - зруйнована труба, $a=1$ - міцність бездефектної труби).

Під час визначення $\mathrm{S}_{\mathrm{EK} 3}$ глибина схематизованого ЕКЗ приймається такою, що дорівнює максимальній глибині ЕК3, а його довжина - обмежується сектором, як це показано на Рисунку 26.

Величина $\mathrm{S}_{\text {деф. }}$ визначається так:

$$
\mathrm{S}_{\text {деф. }}=\mathrm{S}_{\text {бездеф. }}-\mathrm{S}_{\text {ЕК3 }}
$$

Параметр $s_{\min }$ встановлюється за результатами товщинометрії.

Величина s, розраховується з умови граничного стану дефектного перерізу трубопроводу в окружному напрямку:

$$
a\left(s_{R}\right)=0,9 \text {, }
$$

для низки довжин ЕКЗ в осьовому напрямку:

$$
\mathrm{L}=\mathrm{n} \sqrt{0,5 \mathrm{D}_{\text {зовн. }} \mathrm{s}} \text {, }
$$

де $\mathrm{n}=1,2,3,4,6,8$,

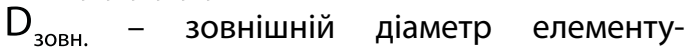
трубопроводу.

Величина $S_{R}$ визначається розрахунковим способом 3 урахуванням вимог п. 4.2 норм на проєктування [13]. Водночас допустимі напруження, використані для встановлення значення $\mathrm{s}_{\mathrm{R}^{\prime}}$ згідно з нормами на проєктування [13] відповідають розрахунковій категорії напружень $(\sigma)_{1}$.

Величина $\mathrm{s}_{2}$ розраховується з умови граничного стану дефектного перерізу трубопроводу в окружному напрямку:

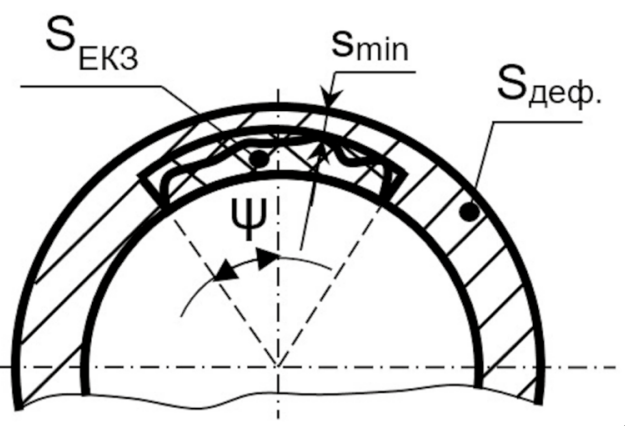

б)

Рисунок 2 - Схема поперечного перерізу: а) - без ЕК3, б) - з ЕК3 


$$
\alpha(\mathrm{s})=0,9[\bar{\sigma}] /[\bar{\sigma}]_{\phi a k m} .
$$

для низки довжин ЕКЗ в осьовому напрямку згідно з формулою (3). У формулі (4) $[\bar{\sigma}]$, $[\bar{\sigma}]_{\text {факт. }}-$ допустимі напруження для елементу трубопроводу 3 ЕK3, що відповідають мінімально гарантованим значенням механічних характеристик норм на проєктування [13] та їх фактичним (паспортним) значенням. За відсутності паспортних даних консервативно приймається $[\bar{\sigma}] /[\bar{\sigma}]_{\text {факт. }}=1$.

у разі наявності фактичних механічних характеристик матеріалу елементу трубопроводу 3 ЕК3 значення $s_{2}$ коректніше встановлювати графічним способом з використанням залежностей безрозмірної глибини ЕK3 $\left(s-s_{\min }\right) / s$ від довжини ЕК3 уздовж осі трубного елементу. Причому $s_{2}$ приймається рівним $\mathrm{s}_{\min }$.

Коефіцієнт а показує у скільки разів міцність труби з ЕКЗ менша міцності бездефектної труби. Аналітичні моделі з оцінки граничного пластичного стану трубопроводу з дефектом осьової орієнтації та відповідні формули визначення коефіцієнта а наведено в роботах [18], [19].

Під час виконання експрес-оцінки нижня границя $s_{1}$ розглядається одночасно 3 урахуванням величини 0,3s, а саме: $\max \left\{\mathrm{s}_{1} ; 0,3 \mathrm{~s}\right\}$. Такий критерій установлено з метою недопущення ситуації, коли геометричні характеристики трубопроводу, значення механічних властивостей матеріалу, внутрішнього тиску і температури будуть такими, що в результаті s, прийматиме занадто низького значення - менше 30 \% від номінальної товщини стінки бездефектного елементу трубопроводу.

Критеріальні значення $\mathrm{s}_{1}$ та $\mathrm{s}_{2}$ обираються 3 урахуванням значення еквівалентної довжини

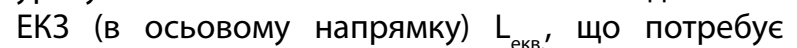
визначення. Схематизуючи ЕК3 напівеліпсом (Рисунок 3), маємо

$$
\mathrm{L}_{\text {екв. }}=2 \mathrm{~L}_{\max } / \pi \text {, }
$$

де $L_{\text {max }}$ - максимальна довжина ЕКЗ в осьовому напрямку трубопроводу.

$У$ разі, коли $L_{\text {екв. }}$ не співпадає з табличним рядом довжин $L$, значення $\mathrm{s}_{1}$ та $\mathrm{s}_{2}$ приймаються такими, що відповідають найближчому до $\mathrm{L}_{\text {екв. }}$ більшому значенню L.

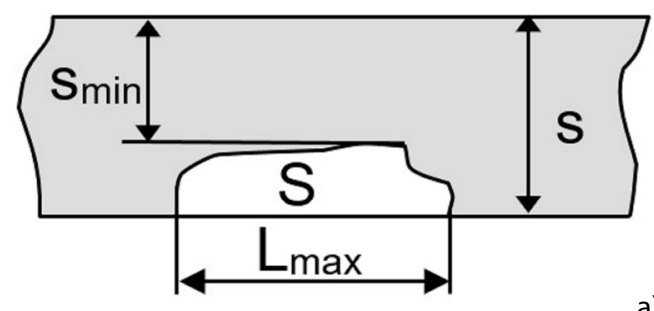

a)
Якщо за результатами експрес-оцінки ЕКЗ виникає потреба у виконанні додаткових розрахункових обгрунтувань, виконується уточнений (додатковий) розрахунок ступеня небезпеки ЕКЗ.

\section{Уточнена оцінка ступеня небезпеки ЕК3}

Уточнений розрахунок ступеня небезпеки ЕКЗ передбачає виконання таких розрахунковоаналітичних робіт:

розрахунок НДС трубопровідної системи в умовах нормальної експлуатації (HE), порушень нормальної експлуатації (ПНЕ), гідравлічних випробувань (ГВ), аварійних ситуацій (АС), сейсмічних впливів (максимальний розрахунковий землетрус (MP3), проєктний землетрус (П3)) для матеріалу без ЕК3 з метою визначення діючих силових факторів;

оцінка ЕКЗ в окружному напрямку поперечного перерізу трубопроводу (для характерного розміру ЕК3 вздовж осі труби). Розрахунок референсних напружень у поперечному перерізі елемента з ЕКЗ в умовах дії внутрішнього тиску, використовуючи моделі [18], [19];

оцінка ЕКЗ в осьовому напрямку трубопроводу (для характерного розміру ЕКЗ в окружному напрямку поперечного перерізу труби). Розрахунок референсних напружень у поперечному перерізі елементу з ЕКЗ виконуються з використанням моделі граничного пластичного стану [20] в умовах одночасної дії внутрішнього тиску, осьового зусилля і моменту згину;

перевірка умови допустимості трубопроводу 3 ЕК3 за допомогою співставлення референсних напружень $\sigma_{r}^{d}$ з допустимими значеннями $[\bar{\sigma}]$ для відповідних розрахункових категорій напружень. Якщо критерії міцності задовольняються, трубопровід з ЕКЗ допускається в експлуатацію, в іншому випадку - підлягає ремонту.

Референсні напруження по своїй суті являють умовну границю міцності матеріалу трубопроводу, за якої дефектна ділянка трубопроводу за прикладеної системи навантажень не зруйнується. Розрахункові значення референсних напружень $\sigma_{r}^{d}$ трубопроводів по своїй природі належать до розрахункових груп категорій напружень $(\sigma)_{2}$ або $(\sigma)_{R K}$ згідно з Таблицею 5.1 норм на проєктування [13].

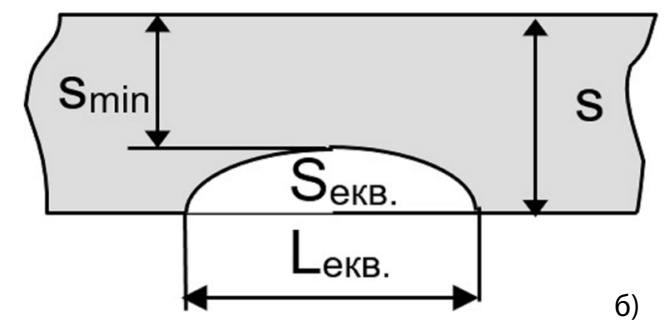

Рисунок 3 - Схематизація ЕК3 в осьовому напрямку трубопроводу: а) - профіль ЕК3, б) - схематизований ЕК3 
Допустимі значення напружень $[\bar{\sigma}]$ для елементів трубопровідної системи за умов ЕКЗ для різних режимів експлуатації та їх сполучень наведені у Таблиці 2.

Наведені у Таблиці 2 значення допустимих напружень $[\bar{\sigma}]$ відповідають вимогам норм на проєктування [13] 3 урахуванням ЕК3, що враховується збільшенням рівня допустимих напружень на $10 \%$.

Отже, розроблений підхід повністю відповідає вимогам норм на проєктування [13], та доповнює їх оцінкою ЕКЗ. Водночас використовується єдина система коефіцієнтів запасу міцності. Це означає, що розроблений підхід і положення норм на проєктування [13] передбачають використання ідентичних категорій напружень, режимів експлуатації та критеріїв граничного стану. Узгоджені також розрахункові параметри, тобто розрахункові формули для визначення рівня навантаженості.

\section{Верифікація розрахункових моделей}

Коректність запропонованих у рамках виконання експрес-оцінки аналітичних розрахункових моделей з визначення коефіцієнта а для різних елементів трубопроводу підтверджена результатами чисельних розрахунків методом скінчених елементів [18], [19].

Додатково 3 метою верифікації аналітичних моделей оцінки залишкової міцності трубопроводів з ЕКЗ осьовою орієнтацією [18], [19] та моделей оцінки залишкової міцності трубопроводів з ЕК3 окружною орієнтацією [20] проведено комплекс повномасштабних випробувань до руйнування елементів трубопроводів з дефектами різної орієнтації та в умовах різного сполучення навантажень, результати яких наведено в [21].

\section{Апробація запропонованого підходу до оцінки ЕКЗ}

У рамках робіт з апробації запропонованого у статті підходу до оцінки ЕКЗ виконана експресоцінка задокументованих стоншень трубопроводів турбінного відділення енергоблоків № 1 і № 4 Відокремленого підрозділу «Запорізька атомна електростанція» (ЗАЕC) за період експлуатації 3 2012 р. по 2016 р.

За вказаний період на енергоблоці №1 ЗАЕС зафіксовано 12 випадків ЕКЗ. Усі стоншення стосуються трубопроводів системи живильної води на ділянці від підігрівачів високого тиску до реакторного відділення. Матеріал, 3 якого виготовлено елементи трубопроводів, в 11 випадкахвідповідає сталі 20, решта-08X18Н10T.

На енергоблоці № 4 ЗАЕС задокументовано 49 випадків ЕК3. 3-поміж систем, у яких зафіксовано найбільшу кількість ЕК3, необхідно виділити трубопровід пари від розширювача продування ПГ (13 випадків), трубопровід сепарата (10 випадків), дренажний трубопровід паропроводу власних потреб до технологічного конденсатору (4 випадки) тощо. Матеріал, з якого виготовлено елементи вказаних трубопроводів у 48 випадках відповідає сталі 20, решта - 08Х18Н10Т.

Кількість та частка прямих ділянок, колін та трійників від загальної кількості проаналізованих елементів трубопровідних систем з ЕКЗ енергоблоків № 1 і № 4 ЗАЕС наведена на Рисунку 4.

Таблиця 2 - Допустимі напружень $[\bar{\sigma}]$ за наявності ЕК3

\begin{tabular}{|c|c|c|c|c|c|c|c|}
\hline \multirow{2}{*}{$\begin{array}{l}\text { Кат. } \\
\text { напр. }\end{array}$} & \multicolumn{7}{|c|}{ Допустимі напруження $[\bar{\sigma}]$} \\
\hline & $\mathrm{HE}$ & ПНЕ & ГВ & $A C$ & $\mathrm{HE}+\mathrm{MP} 3$ & $\begin{array}{c}\text { НЕ+ПЗ } \\
\text { (І кат.) }\end{array}$ & $\begin{array}{c}\mathrm{HE}+П 3 \\
\text { (II кат.) }\end{array}$ \\
\hline$(\sigma)_{2}$ & $1,1[\sigma]$ & $1,1 \cdot 1,2[\sigma]$ & $1,1 \cdot 1,35[\sigma]$ & $1,1 \cdot 1,4[\sigma]$ & - & - & - \\
\hline$(\sigma)_{R K}$ & \multicolumn{2}{|c|}{$\begin{array}{l}\frac{1,1}{1,3} \cdot\left(2,5-\frac{\sigma_{T}}{\sigma_{B}}\right) \sigma_{T} \\
\text { але не більше } \\
\frac{1,1}{1,3} \cdot 2 \sigma_{T}\end{array}$} & - & $\begin{array}{c}\frac{1,1}{1,3} \cdot\left(2,5-\frac{\sigma_{T}}{\sigma_{B}}\right) \sigma_{T} \\
\text { але не більше } \\
\frac{1,1}{1,3} \cdot 2 \sigma_{T}\end{array}$ & - & - & - \\
\hline$\left(\sigma_{s}\right)_{2}$ & & - & - & - & $1,4 \cdot 1,1[\sigma]$ & $1,2 \cdot 1,1[\sigma]$ & $1,5 \cdot 1,1[\sigma]$ \\
\hline
\end{tabular}




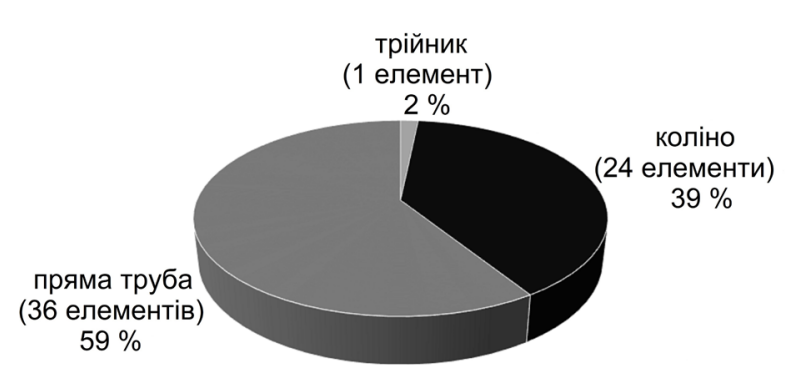

Рисунок 4 - Кількість елементів трубопроводів 3АЕС-1,4 з пошкодженнями типу ЕКЗ за період 2012 - 2016 рp.

Співставлення результатів оцінки ЕКЗ трубопроводів енергоблоків № 1 і № 4 ЗАЕС за допомогою існуючого підходу [14] та з використанням запропонованої у статті експрес-оцінки наведено на Рисунку 5, де сектор 1: згідно 3 [14] - ремонт, експрес-оцінка - уточнений розрахунок; сектор 2: згідно 3 [14] - ремонт, експрес-оцінка - ремонт; сектор 3: згідно 3 [14] - допускається в експлуатацію, експрес-оцінка - уточнений розрахунок. Відповідно до діаграми на Рисунку 5 для 35-ти ЕК3 згідно з існуючим підходом [14] товщини стінок у зоні ЕКЗ менші мінімально допустимих значень (тобто потребують ремонту), тоді як, згідно 3 розробленим підходом до експрес-оцінки, всі 35 вказаних елементів трубопроводів підлягають уточненому розрахунку (сектор 1 Рисунку 5). Для 13-х ЕК3 (сектор 2) результат обидвох підходів ідентичний - ремонт. Для 13-х ЕК3 (сектор 3) згідно з існуючим підходом [14] товщини стінок у зоні ЕK3 перевищують мінімально допустимі значення (тобто допускаються в експлуатацію), тоді як, згід-

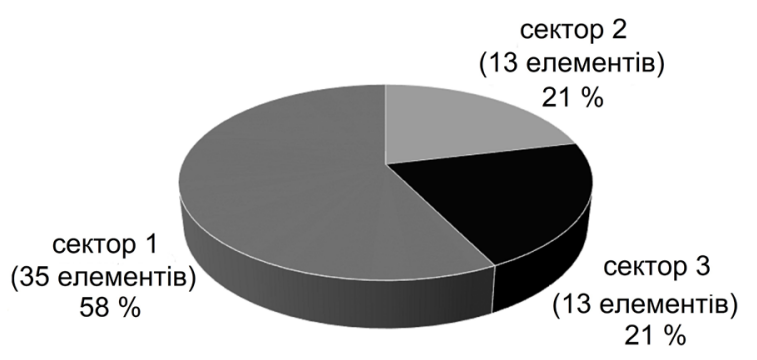

Рисунок 5 - Порівняння результатів оцінки ЕК3 ЗАЕC-1,4 за допомогою існуючого підходу [14] та розробленого у статті підходу (експрес-оцінка)

но з розробленим підходом до експрес-оцінки, всі 13 указаних елементів трубопроводів потребують додаткового уточненого розрахунку.

Додатково зауважимо, що за результатами аналізу ЕКЗ енергоблока № 1 ЗАЕС з використанням існуючого підходу [14] для всіх 12 випадків товщини стінок у зоні ЕК3 менші мінімально допустимих значень (ремонт), тоді як, згідно з розробленим підходом до експрес-оцінки, необхідність ремонту встановлено тільки для 4-х випадків, для решти виконання уточненого розрахунку.

3 метою апробації процедури уточненого розрахунку ЕК3, що поряд із експрес-оцінкою $є$ складовою запропонованого у статті підходу, проведено комплекс розрахунків для 4-х ЕК3, виявлених в трубопроводах живильної води ( $\varnothing 108 \times 6, \varnothing 108 \times 8$, $\varnothing 108 \times 9$, матеріал ст20, 08Х18Н10Т) на ділянці від підігрівачів високого тиску до реакторного відділення енергоблока № 1 ЗАЕС в період експлуатації з 2013 р. по 2015 р. Схема трубопроводів з місцями розташування ЕКЗ зображена на Рисунку 6.

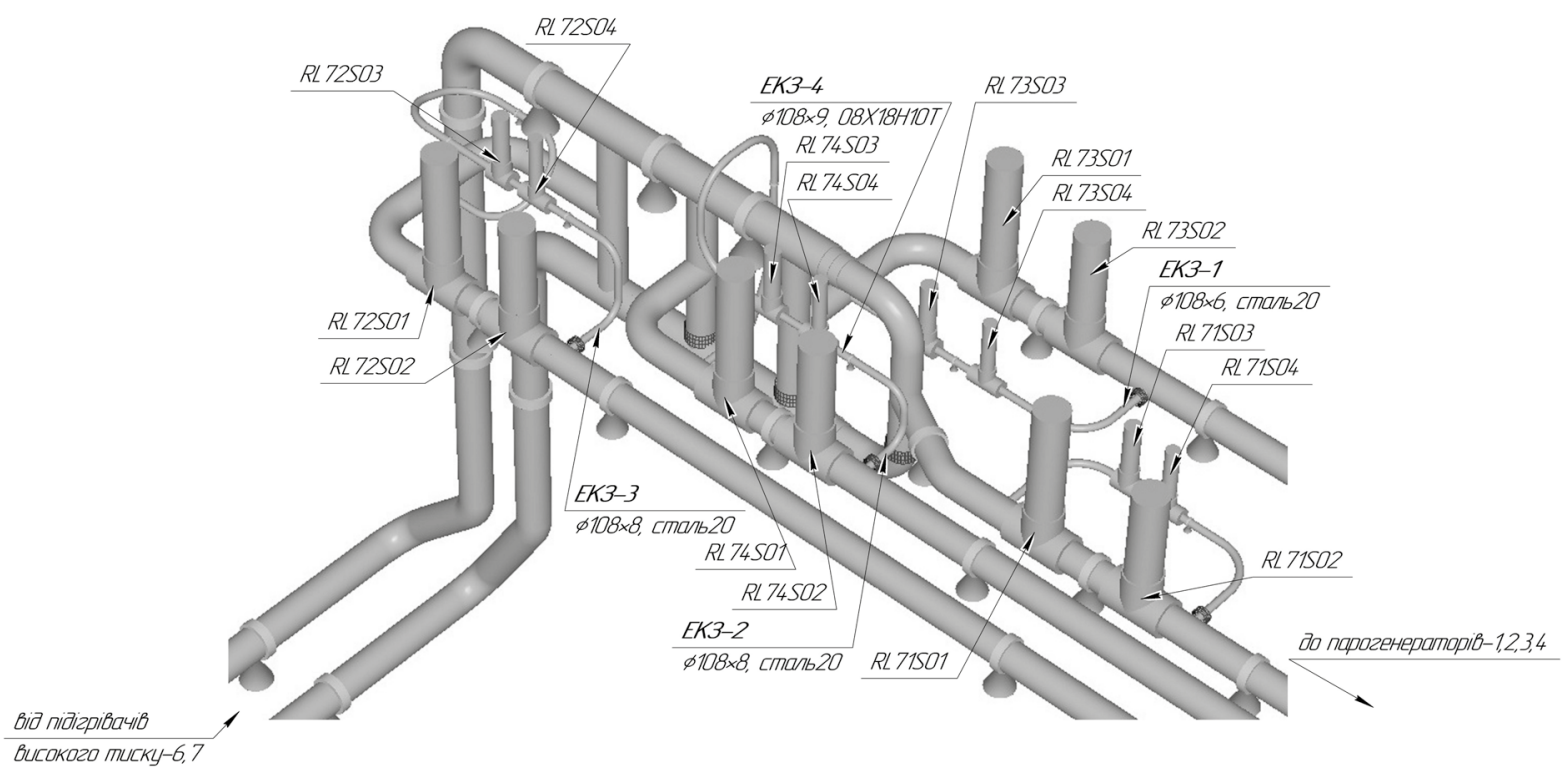

Рисунок 6 - Схема трубопроводів ЗАЕС-1 з місцями розташування ЕКЗ 
Уточнений розрахунок ЕКЗ вказаних трубопроводів в умовах розрахункового режиму НЕ та комбінації режимів $\mathrm{HE}+П 3$ показав такі результати: для ЕК3-1,4 умови міцності задовольняються для всіх режимів (допускаються до експлуатації), а для ЕК3-2,3 - міцність при $\mathrm{HE}$ забезпечується, при НЕ+ПЗ - коефіцієнти запасу міцності трохи менші одиниці (потребують ремонту). Згідно зі спрощеним існуючим підходом [14], як зазначалось вище, експлуатація всіх 4-х ЕК3 не допускається (ремонт).

\section{Висновки}

Ступінь небезпеки ЕК3 трубопровідних систем на енергоблоках АЕС України оцінюється за спрощеною процедурою [14], що базується на розрахунку мінімально допустимих товщин стінок бездефектних елементів трубопроводів згідно з нормами на проєктування [13]. На відміну від повірочного розрахунку, такий підхід враховує тільки однофакторне навантаження внутрішнім тиском, що 3 огляду на складну просторову конфігурацію трубопроводів АEC, у яких виникають зусилля і моменти, призводить до отримання некоректних i, що головне, неконсервативних результатів.

Запропонований у статті підхід до оцінки ступеня небезпеки ЕК3, що передбачає виконання експрес-оцінки і уточненого розрахунку, порівняно з існуючим підходом [14], має низку переваг. По-перше, ЕКЗ оцінюється для двох характерних напрямків: окружного (від дії внутрішнього тиску) та осьового (з урахуванням дії внутрішнього тиску, осьового зусилля та моментів згину). По-друге, ЕКЗ оцінюється не лише $з$ урахуванням його глибини, а й довжини й ширини.

Коректність розрахункових моделей [18]-[20], які покладено в основу розробленого підходу, підтверджена результатами чисельних розрахунків і серією повномасштабних випробуваньдефектнихелементів трубопроводів до руйнування [21]. Підхід до оцінки ступеня небезпеки ЕКЗ апробовано за результатами виконання комплексу розрахунково-аналітичних робіт з оцінки виявлених стоншень у період експлуатації з 2012 р. по 2016 р. трубопроводів турбінного відділення енергоблоків №1 і №4 3AEC.

Запропонований підхід покладено в основу відповідної методології визначення допустимих товщин елементів трубопроводів AEC $з$ вуглецевих сталей, схильних до ЕК3 [22], погодженої Державною інспекцією ядерного регулювання України (лист від 19.08.2019 № 15-46/10145-9637 [23]).

\section{Список використаної літератури}

1. Бараненко В.И., Алешин Г.Н., Васильев В.Г., Кравченко В.П., Трубкина Н.Е. Влияние эрозионнокоррозионного износа оборудования, трубопроводов и арматуры на надежность и безопасность блоков АЭС ВВэР. Мировая электроэнергетика. 1996. № 2. С. 25-27.

2. Томаров Г. В., Поваров В.П. Шипков А. А., Громов А. Ф., Киселев А. Н., Шепелев С. В., Галанин А.В. Разработка и применение информационно-аналитического комплекса по проблеме эрозии-коррозии элементов трубопроводов II контура энергоблоков Нововоронежской АЭС с РУ ВВЭР-440. Теплоэнергетика. 2015. № 2. С. 63-68.

3. Scott P., Vaillant F. History of corrosion and mechanical degradation in operating plants - plant affected areas and actions. Second International conference on Flow Accelerated Corrosion (FAC 2010). Proceedings. 2010. Lyon, France.

4. Авария на АЭС «Сарри». Атомная техниказа рубежом. 1987. № 10. С. 43.

5. Кастнер В., Ноппер Х., Рёснер Р. Защита трубопроводов от коррозионной эрозии. Атомная энергия. 1993. Т. 75. Вып. 4. С. 286-294.

6. Secondary Piping Rupture Accident at Mihama Power Station Unit 3 of Kansai Electric Power Co. Inc. (Final Report). Japan : The Nuclear Industrial Safety Agency, 2005. 116 p.

7. Kain V., Roychowdhury S., Mathew T., Bhandakkar A. Flow accelerated corrosion and its control measures for the secondary circuit pipelines in Indian nuclear power plants. Journal of Nuclear Materials. 2008. V.383(1-2). P. 86-91. doi: 10.1016/j.jnucmat.2008.08.024.

8. Hwang K.M., Jin T.E., Lee S.H., Jeon S.C. Wall thinning trend analyses for secondary side piping of Korean NPPs (0022). 1 $7^{\text {th }}$ International Conference on Structural Mechanics in Reactor Technology (SMiRT-17). Transactions. 17-22 August, 2003, Prague, Czech Rep., No. O02-5. URL: http://www.lib.ncsu.edu/resolver/1840.20/27398.

9. Бараненко В.И., Пионтковский А.И., Туркин В.Е. О характере эрозионно-коррозионного износа трубопроводов на первом энергоблоке Южно-Украинской АЭС. Теплоэнергетика. 1996. № 12. С. 55-60.

10. Shreir L. L., Jarman R. A., Burstein G. T. (Eds.) Corrosion. Metal/Environment Reactions. Volume 1. $3^{\text {rd }}$ ed. : ButterworthHeinemann, 2000.1432 p.

11. Бараненко В.И., Гулина О.М., Нафталь М.М., Арефьев А. А., Юрманов В. А. Использование программных средств для расчета эрозионно-коррозионного износа. Сборник трудов 8-й международной научно-технической конференции «Обеспечение безопасности АЭС с ВВЭР». 28 - 31 мая, 2013 г., ОКБ «Гидропресс», Подольск, Россия.

12. СОУ НАЕК 040:2017. Инженерная, научная и техническая поддержка. Управление старением оборудования и трубопроводов АЭС, склонных к эрозионнокоррозионному износу. Общие требования. Затвердж. наказом ДП «НАЕК «Енергоатом» від 14.02.2017 № 153.

13. ПНАЭ Г-7-002-86. Нормы расчета на прочность оборудования и трубопроводов атомных энергетических установок. М. : Энергоатомиздат, 1989. 524 с. 
14. ИН-Т.0.03.190-14. Унифицированная инструкция по проведению измерения толщины стенок элементов трубопроводов, подверженных эрозионно-коррозионному износу, с помощью ультразвука.

15. API RP 579. Recommended Practice for Fitness for Service. American Petroleum Institute, 2000. 448 p.

16. РД ЭО 0571-2006. Нормы допустимых толщин элементов трубопроводов из углеродистых сталей атомных станций. М. : ОАО «Концерн Росэнергоатом», 2006. 44 с.

17. МТ-Т.0.03.208-10. Методика расчетов трубопроводов АЭС в рамках концепции «течь перед разрушением». Введено В дію розпорядженням ДП «НАЕК «Енергоатом» від 23.12.2010 № 1087p.

18. Orynyak I., Ageiev S., Radchenko S., Zarazovskii M. Local limit load analytical model for thick-walled pipe with axial surface defect. J. Pressure Vessel Technol. 2015. V. 137(5): 051204. doi: 10.1115/1.4029523.

19. Orynyak I., Ageiev S. The limit load analytical model for pipe branch with axial surface defect. $22^{\text {nd }}$ International Conference on Structural Mechanics in Reactor Technology. SMiRT-22. Transactions. 18-23 August, 2013 San Francisco, USA., No.364. URL: http://www.lib.ncsu.edu/ resolver/1840.20/32739.

20. Orynyak I., Ageiev S., Radchenko S. Local and global reference stress for circumferential irregular-shaped defects in pipes. J. Pressure Vessel Technol. 2015. V. 137(4): 041203. doi: 10.1115/1.4028680.

21. Orynyak I. V., Vlasenko N. I., Kozlov V. Ya., Andrieshin Ya. A., Chechin É. V., Buiskikh K. P., Ageev S. M., Yanko O. A. Test results for edge-notched pipe specimens within framework of experimental substantiation of the leak-before-break phenomenon. Strength of materials. 2012. V. 44(5). P. 562-573. doi: 10.1007/s11223-012-9409-y.

22. МТ-Т.0.03.224-18. Методика определения допустимых толщин элементов трубопроводов АЭС из углеродистых сталей подверженных действию эрозионно-коррозионного износа.

23. Лист Держатомрегулювання від 19.08.2019 №15-46/10145-9637.

\section{References}

1. Baranenko, V., Alioshyn, G., Vasiliev V., Kravchenko V., Trubkina N. (1996). Influence of erosion-corrosion wear of equipment, pipelines and valves on the reliability and safety of VVER NPP units. World Electricity, 2, 25-27.

2. Tomarov, G., Povarov, V., Shypkov, A., Gromov, A., Kisieliov, A., Shepelev, S., Galanin, A. (2015). Development and application of an information and analytical complex on the issue of erosion-corrosion of secondary piping components of the Novovoronezh NPP with WWR-440. Heat Power Engineering, 2, 63-68.

3. Scott, P., Vaillant, F. (2010). History of corrosion and mechanical degradation in operating plants - plant affected areas and actions. Proceedings, Second International conference on Flow Accelerated Corrosion (FAC 2010). Lyon, France.

4. Surry NPP accident. (1987). Atomic Engineering Abroad, 10,43 .

5. Kastner, W., Nopper, H., Rössner, R. (1993). Prevention of piping degradation due to erosion corrosion. Atomic Energy, 75 (4), 286-294.

6. Secondary Piping Rupture Accident at Mihama Power Station Unit 3 of Kansai Electric Power Co. Inc. Final Report. (2005). Japan, The Nuclear Industrial Safety Agency, 116.

7. Kain, V., Roychowdhury, S., Mathew, T., Bhandakkar, A. (2008). Flow accelerated corrosion and its control measures for the secondary circuit pipelines in Indian nuclear power plants. Journal of Nuclear Materials, 383(1-2). 86-91. doi: 10.1016/j.jnucmat.2008.08.024.

8. Hwang, K., M., Jin, T., E., Lee, S., H., Jeon, S., C. (2003). Wall thinning trend analyses for secondary side piping of Korean NPPs (0022). Transactions, $17^{\text {th }}$ International Conference on Structural Mechanics in Reactor Technology. SMiRT-17, Prague, Czech Rep., No.O02-5. URI: http://www.lib.ncsu.edu/ resolver/1840.20/27398.

9. Baranenko, V., Piontkovskiy, A. et al. (1996). On the nature of erosion-corrosion wear of pipelines at South-Ukraine NPP Unit 1. Heat Power Engineering, 12, 55-60.

10. Shreir, L., L., Jarman, R., A., Burstein, G., T. (Eds.) (2000). Corrosion. Metal/Environment Reactions, 1(3). ButterworthHeinemann, 1432.

11. Baranenko, V., Gulina, O., Naftal, M., Arefiev, A., Yurmanov, V. (2013). Software usage for calculating erosion-corrosion wear. Proceedings, $8^{\text {th }}$ International Scientific and Technical Conference: Safety Assurance of WWER NPP. EDO Gidropress. Podolsk, Russian Federation.

12. SOU NAEK 040:2017. Engineering, scientific and technical support. Aging management of NPP equipment and piping prone to flow accelerated corrosion. General requirements. Approved by Energoatom Order No. 153 of 14 February 2017.

13. PNAE G-7-002-86. (1989). Standards for strength calculation of NPP equipment and piping. Moscow, Energoatomizdat, 524.

14. IN-T.0.03.190-14. Unified instructions for measuring wall thickness of pipeline elements subject to erosion-corrosion wear using ultrasound.

15. API RP 579. (2000). Recommended practice for fitness for service. American Petroleum Institute, 448.

16. RD EO 0571-2006. (2006). Standards of allowable wall thicknesses for NPP pipeline elements made of carbon steel. Moscow, JSC Rosenergoatom, 44.

17. MT-T.0.03.208-10. Methodology for calculating NPP pipelines within the leak-before-break concept.

18. Orynyak, I., Ageiev, S., Radchenko, S., Zarazovskii, M. (2015). Local limit load analytical model for thick-walled pipe with axial surface defect. Journal of Pressure Vessel Technology, 137(5). doi: 10.1115/1.4029523.

19. Orynyak, l., Ageiev, S. (2013). The limit load analytical model for pipe branch with axial surface defect. Transactions, $22^{\text {nd }}$ International Conference on Structural Mechanics in Reactor Technology. SMiRT-22, San Francisco, USA, No. 364. URI: http://www.lib.ncsu.edu/resolver/1840.20/32739. 
20. Orynyak, I., Ageiev, S., Radchenko, S. (2015). Local and global reference stress for circumferential irregular-shaped defects in pipes. Journal of Pressure Vessel Technology, 137(4). doi: 10.1115/1.4028680.

21. Orynyak, I., Vlasenko, N., Kozlov, V., Andrieshin, Ya., Chechin, É., Buiskikh, K., Ageev, S., Yanko, O. (2012). Test results for edge-notched pipe specimens within framework of experimental substantiation of the leak-beforebreak phenomenon. Strength of materials, 44(5). 562-573. doi: 10.1007/s11223-012-9409-y.

22. MT-T.0.03.224-18. Methodology for determining the allowable wall thicknesses of NPP piping components of carbon steels under erosion-corrosion wear.

23. Letter of the SNRCU No. 15-46/10145-9637 of 19 August 2019.

\section{Methodology for Assessing the Allowable Wall Thicknesses of Carbon Steel NPP Piping under Erosion-Corrosion Wear}

\section{Ageiev S.}

\section{IPP-Centre LLC, Kyiv, Ukraine}

The approach for assessing the hazard of erosion-corrosion wear for elements of NPP piping made of carbon steels has been developed. In order to test the developed approach, a set of calculation and analytical activities have been performed, in particular:

a) the existing approach for assessing the hazard of erosion-corrosion wear has been analyzed and its shortcomings have been established;

b) an algorithm for assessing the hazard of erosion-corrosion wear using rapid assessment and refined procedure has been developed;

c) the analytical models have been verified by comparison with other existing computer models and experimental data to demonstrate their correctness;

d) the hazard assessment of erosion-corrosion defects of piping at Zaporizhzhya NPP Units 1 and 4 detected during operation from 2012 to 2016 has been performed according to the proposed approach.
The proposed approach allows:

1) the hazard of erosion-corrosion wear to be assessed not only in the circumferential direction of the piping cross-section under internal pressure (approach based on standard requirements PNAE G-7-002-86 in terms of determining the allowable wall thickness of defect-free piping) but also in the piping axial direction under internal pressure, axial force and bending moment. This approach is especially relevant for piping that usually has a complex 3-D configuration, which leads to axial forces and bending moments under the action of weight characteristics, temperature, seismic effects, etc.;

2) the hazard of erosion-corrosion wear to be assessed not only by its depth (approach IN-T.0.03.190-14) but also taking into account its length and width. Contrastingly to the existing approach, this affords more accurate assessment of the hazard posed by erosion-corrosion wear.

Keywords: NPP, piping, erosion-corrosion wear, strength, rapid assessment, refined analytical procedure.

Отримано 09.03.2021 